(115)

\title{
Green Building Rating Systems: Present Status, Challenges and Future Perspectives
}

\author{
Maheepala S.A.D.S.S., Ukwattage M.I., Madugoda P.M., Jayasinghe G.Y.* \\ Department of Agriculture Engineering, University of Ruhuna, Sri Lanka \\ *victorlion3000@gmail.com
}

\begin{abstract}
Extensive urbanisation frequently results adverse effects on natural environment since it is altered by anthropogenic activities and resulted newly built constructions. Heat Island Effect and sick building syndrome which caused by conventional buildings are badly affecting the human health. Life cycle of traditional buildings and building continuations are harmful to environmental and human well-being and it harms to the sustainability of entire ecosystem. Green building concept is one of the best strategy to maintain the sustainability in the recent construction industry. Green Building Rating System is the most appropriate way to evaluate a green building whether it has been built with proper sustainable practices. Green building rating systems mainly address the building environmental performance and give directions to measure the performance. Different green building rating systems are used around the world such as BREEAM, LEED, Green Star and Green Building index and they have gained increased attention due to their scoring system, composition, cost and consideration. Many types of green buildings are constructed and certified in the world by using these rating systems. Green building rating systems mainly evaluate the building performance from design stage to the operational stage using different criteria such as Site selection, Water efficiency, Energy efficiency, material selection, occupant health and comfort and etc. It helps to minimize the resource consumption and waste generation and allocate resources for optimum consumption throughout the building life cycle. Different rating systems have its own strengths and weaknesses when compared with each other rating systems. Every country should use their own green building rating system by considering their social, economic, geographic and environmental conditions to achieve the optimum performance of the green building rating system. Further, rating systems should be updated with new versions by using new technological advancements. Researches should be focused on green building sector to design better versions of rating systems. This paper examines a comprehensive review of existing literature with the present status of green building sector, comparison of different green building rating systems, their advantages, drawbacks, present challenges and future perspectives.
\end{abstract}

Keywords: Green building rating systems, LEED, BREEAM, Green building index, Urbanization 